\title{
Impact of the 1956 Hungarian Revolution in Argentina
}

\author{
Judith Kesserü Némethy (New York University, NY)
}

\begin{abstract}
The outbreak of the Hungarian revolution in 1956 brought forth solidarity movements from Hungarian émigrés all over the world. In Argentina, the response was overwhelming. Hungarian émigré organizations formed a "Comité de Ayuda pro Hungría Libre" (Aid Committee for a Free Hungary), coordinating the strategies and actions aimed at providing moral and material support for the revolution. Supplementing and aiding these actions were those of the Argentine government and population at large. The government named a special commission for refugees; and there was a tremendous outpour of sympathy and material support for Hungarians among Argentines, with major press coverage for months to come. Of special importance is the literary and press output following the revolution. These actions provoked fear and rejection from the Embassy of the People's Republic of Hungary, and it accused the Argentine government of openly siding with the émigrés. Upon the Hungarian Foreign Ministry's instructions, the Embassy strongly intensified the espionage on the émigré institutions and its prominent members for years. Relations between émigré organizations and the Hungarian Government remained nonexistent or strained until the lifting of the Iron Curtain in 1990.
\end{abstract}

The outbreak of the Hungarian revolution on October 23rd, 1956 brought forth solidarity movements from Hungarian émigrés and their environment all over the world. It has justifiably been called "the cleanest revolution," for Hungarians were probably never as united as during those days, and during the long months and years of retribution that followed. Émigrés saw only one mission for themselves: to help the fighting nation.

In Argentina, the response was overwhelming. Among the émigrés of 1948, differences between left and right disappeared as churches, associations, clubs and youth groups worked together to help the freedom fighters and later the refugees, as well as those who couldn't escape. Through marches, protests, masses, donations, petitions, publications and exhibitions, all of émigré society was mobilized. ${ }^{1}$

On October 25th, 1956, leaders of the Hungarian émigré organizations sent telegrams to Argentina's President Pedro Eugenio Aramburu, US President Dwight Eisenhower, UN Secretary General Dag Hammarskjöld, as well as, among others, to the Argentine, Cuban and Peruvian Ambassadors to the UN, to the Austrian Chancellor, to the President of Yugoslavia, and to the International Red Cross ${ }^{2}$. They urged authorities to voice their support in protecting the people of Hungary against the reprisal of the Soviet-led Communist government, and to speak out on behalf of their human rights.

On October 27th, more than 10,000 people gathered at the Metropolitan Cathedral in Buenos Aires for prayers and the celebration of a mass in Hungarian and Spanish. From there, the crowd marched in silence through the city streets to place a wreath at the foot of the statue of

1 In contrast, Gyula Borbándi wrote the following in his book A magyar emigráció életrajza 1945-1985 [ Biography of the Hungarian emigration 1945-1985: "The outbreak of the Revolution did not provoke any special activity among the Hungarian émigrés in the West. Since nobody counted with its possibility in the near future, no preparations were made for the event of an eventual outbreak. Politicians, journal publishers, heads of the associations, editors and publicists listened to the radio transmissions and read the news, analyzing and commenting the events in Hungary and around the world during the 14 days of the popular uprising and of the freedom fight." [Vol. 1, p. 401]

2 Antal Sorg: : Beszámoló a "Szabad Magyarország Segítő Bizottsága” megalakulásáról és működéséről. 
José de San Martín, the hero of Argentina's independence. Composed of Hungarians, members of sister emigrations from behind the Iron Curtain, and Argentines, the formation was a kilometer long, in lines of four, dotted with flags and enormous placards. ${ }^{3}$

On October 30th, leaders of the Centro Húngaro (Argentina's most important Hungarian club) invited the heads of all Hungarian émigré organizations to form the Committee of Assistance for a Free Hungary, in order to coordinate the strategies and actions aimed at providing support for the revolution. It acted through subcommittees - press and publicity, monetary, social services and activities, foreign affairs, transportation and youth -all coordinated by a central secretariat.

The movement had two main elements. One branch focused on the moral and material support of the fighting nation through an extensive collection of donations in money and kind to be categorized, packed and shipped. The second branch managed the reception and assistance of the refugees, arranging for housing and assisting with job searches. The club's facilities were crowded with dozens of volunteers working in shifts from 8 a.m. to midnight, collecting, sorting, classifying, and packaging the mounds of food, clothing, blankets and medicines. Over 2,500 bags and crates were shipped to Hungary during those days. Citizens formed long lines to donate money and goods. Others signed up to donate blood. During its four weeks of work in the Centro, the Assistance Committee received a total of $1,200,000$ pesos, and shipped by air and sea over 80,000 kilos of clothing, food, and medication. ${ }^{4}$

These numbers reflect the solidarity of the Argentine people, who throughout the upheaval showed their generosity and support. The memories of the bloody 1955 Argentine revolution that ousted Perón were still fresh, and they followed with sympathy the events in Hungary. They gave immeasurable proof of this through anonymous donations of money, jewels and goods. The Argentine Red Cross made 2000 units of blood available to the Viennese Red Cross, at which point university students en masse offered to replenish the supply. The Secretary of Aviation, upon learning that more than 200 exiles enlisted to join the freedom fighters, offered the assistance of the Argentine Air Force to transport them to Hungary. (The revolution was crushed before this action could materialize). ${ }^{5}$ When word went out that orphans were fleeing Hungary in great numbers, over 11,000 Argentines volunteered to adopt them, while the Argentine government offered homes to 3,000 children. The country appropriated the declaration made by President Aramburu: "In every Argentine heart there must live a small Hungary." Thousands of letters of support and solidarity arrived from every corner of the nation. ${ }^{6}$

In order to facilitate immigration procedures for refugees, the Argentine Government created, on November 19th, a National Commission of Aid to Hungary, presided over by the Foreign Minister. The Asociación Cultural Argentina pro Hungría, formed by prominent members of Argentine society before the revolution, mobilized all of its connections to help the cause of the

3 Embassy of the Hungarian People's Republic. 10.30.1956. [Hungarian National Archives (MOL) XIX-J-1-j-00495-332/56, 5. box, Ambassador Sándor Nagy to Imre Horváth Minister of External Affairs]. "Situation of our embassy with regard to the latest events in Hungary. I inform Comrade Minister that the latest events in our homeland activated the fascist groups residing in Argentina: Hungarians as well as of other nationalities. During the observation of their activities, we found out through our friends that they are preparing a large-scale manifestation against our embassy for October 27 .... They prepared the meeting of the multitudes organizing a large-scale Mass. ...

4 The motto was: "Kétszer ad, aki gyorsan ad" [He who gives fast gives twice]. Magyar Ház Értesítője, Dec. 1956.

5 According to Domonkos Ladányi and Zsigmond Endre's letters to Zsuzsánna Kesserü de Haynal. Sept. 2006.

6 Zsuzsánna Kesserü de Haynal. “1956. október - Buenos Airesben” Krónika (Toronto), Oct. 1986 p. 6-9. 
Revolution. The Hungarian émigré Catholic school provided full scholarships to 26 refugee children. These efforts were broadcast to Hungary by the Voice of America. ${ }^{7}$

The newspaper Délamerikai Magyarság (Hungarians in South America) made an enormous effort to propagate the Hungarian fight for freedom. Within hours after the outbreak of the revolution, this paper, through the Associated Press, broadcast Argentine-Hungarians' protests against the use of Soviet troops in Hungary. It provided the thrust behind a series of press conferences, communiqués, articles, radio and TV publicity that were disseminated around South America. ${ }^{8}$

The paper also carried out considerable political action, and high ranking leaders from all Argentine political parties except the Communists took an active part. After the crushing of the Revolution and the retribution that followed, a series of mass demonstrations and protests were organized in front of both the Hungarian and Soviet embassies, in which crowds of Argentine sympathizers also took part. Some of these demonstrations became violent, with cars being burned in front of the Soviet embassy. ${ }^{9}$

Throughout 1957, demonstrations, protests, masses, prayer groups and conferences continued. On the first anniversary of the revolution a huge exhibition was organized in the Casa de Mendoza in Buenos Aires. More than 150,000 people visited it in two weeks, and 25,000 signatures were collected and sent to the United Nations, demanding that Soviet troops leave Hungary. The exhibition was then taken to several Argentine cities, as well as to Montevideo and Santiago de Chile. ${ }^{10}$

Of special importance is the literary and journalistic output in Argentina following the revolution. Numerous books, journals and periodicals documenting the events were published in Spanish and distributed among Argentine officials as well as government agencies of all Spanish speaking countries, embassies, and UN delegations. For years to come, Hungarian journalists in Argentina were dedicated to keeping alive the spirit of the revolution through news, photographs,

7 Embassy of the People's Republic of Hungary. 9.14.57. [MOL XIX-J-1-j, 11.d.] Activity of the right-wing émigrés in Argentina. "On September 7 the Association of European Captive Nations held an assembly in Buenos Aires with relation to the General Assembly of the United Nations of September 10. Next day the press informed in long articles about this assembly, in which "representatives" of the following 9 countries took part: Albany, Bulgaria, Checoslovakia, Estonia, Letonia, Lithuania, Hungary, Poland, and Rumania. On behalf of Argentina, Dr. Rodolfo Medina, president of the Asociación Cultural Argentina pro Hungría Libre, took part and also gave a speech. In the assembly there were 10 speakers of different nationalities, who praised the "heroic acts" of the October counterrevolution. Stanislaw Sliwinski, president of the Association of European Captive Nations, in the name of the "delegations" of the 9 countries expressed the hope that the U.N. Extraordinary Assembly, which met on September 10, finds a remedy to resolve the Hungarian problem. He demanded "freedom" for the 9 nations and declared the participants' solidarity with the Hungarian nation - and here he obviously referred to the counterrevolutionaries.

8 Embassy of the People's Republic of Hungary. 1.17.1957. [MOL XIX-J-1-j-00480/38/1957, 5.d.] "Press summary: How does Argentina react to the events in Hungary. The events in Hungary were at the center of the Argentine press's attention for the past months. The tone of the news about the events is based on the influence of Western press agencies on Latin America. From the start, the news, information and comments had the following three principal characteristics: 1 . Huge volume of false news. 2. Attempt at creating panic with its hysterical tone. 3. Argentines also took part in this press campaign and centralized propaganda, in which national and foreign fascist elements also participated very actively.

9 Zsuzsánna Kesserü de Haynal, op. cit., p. 7

10 Embassy of the People's Republic of Hungary. 12.31.1960. [MOL XIX-J-1-j. 20/b 10. d.] "Diary of events of the Hungarian emigraton in Latin-America during 1960. March 16, 1960. ... The right-wing newspaper D.M.C. (sic) organized in the Argentine sea-side resort city of Mar del Plata an exhibition on the counterrevolution, under the title "Hungría no se rinde" [Hungary does not surrender]. The exhibition was previously held in Buenos Aires, Córdoba and Mendoza." 
poems, and manifestos. They reported on Cardinal Mindszenty's radio messages, on the refugees, on other émigré groups' activities of support. They also built strong ties with the Argentine press, writing articles and editorials in Spanish for the public at large. Frente Común, Argentina's forceful Anti-Communist paper, printed news from Hungary in each of its weekly issues. Hundreds of articles and radio broadcasts appeared for months in all main newspapers and radio stations as well.

For two years, Délamerikai Magyarság dealt almost exclusively with the revolution. The 1957 Almanac published the content of all Hungarian radio broadcasts - the free, revolutionary ones as well as those under Soviet occupation - from October 23rd to November 4th, hour to hour, minute to minute. It was translated into Spanish that same year 1957 as S.O.S. El drama de Hungría, with illustrations by Lajos Szalay. ${ }^{11}$ Although the drawings were made thousands of kilometers away from Hungary, few artistic creations could convey more vividly the tragedy of the revolution and its suppression. The iconography is at once realistic and apocalyptic in its description of the violence and the feelings of violation and defeat. The publication and wide distribution of this book in Spanish, together with iHungría no se rinde! (Hungary does not surrender), with 10,000 copies printed of each, are the paper's most forceful and lasting contribution to the cause of the revolution.

From 1957 to 1966, over 25 Spanish-language books and brochures on the revolution were published in Argentina. Examples include, among others, Hungría en sangre [Hungary in Blood], La revolución popular húngara. Hechos y documentos [The Hungarian Popular Revolution: Facts and Documents], reports by the UN Special Commission and the Commission of International Jurists on Hungary, the Spanish translation of the White Book on the Hungarian Revolution (based on actual documents) ${ }^{12}$, poetry anthologies and novels. Most informative was Elemér Vácz's bibliography in Spanish covering about 350 publications from the Western world, all dealing with the 1956 revolution.

\section{The Embassy of the People's Republic of Hungary and the 1956 revolution}

The events that broke out in Hungary and their echo in Argentina provoked fear and denial among the personnel of the Embassy of the People's Republic of Hungary. The fact that both the Argentine authorities and most of the population at large sided openly with the revolution, together with the marches, the protests, the series of articles, the exhibitions, the outward expressions of

11 Lajos Szalay, the world-famous graphic artist, lived in Argentina between 1948 and 1960. He was a professor at the National University of Tucumán, and at the Escuela Superior de Bellas Artes of Buenos Aires. He emigrated to New York as a consequence of his drawings on 1956: "In South America, as in many other parts of the world in those days, the active leaders of the cultural life were communists, and I naturally moved in intellectual circles at university level. Thus my situation became difficult as soon as I spoke up on behalf of the suffering of the Hungarian people. ... The situation in Argentina became unsustainable, my daughter received death threats from strangers, so I had to move away with panicky speed." [Lajos Szalay: Végtelen a tenyérben [The infinite in the palm of the hand]. Interviews with Péter Bakonyi. Budapest: Múzsák, 1987.]

12 People's Republic of Hungary. 6.5.1959 [MOL XIX-J-1-k. Arg.4/j.3.d.] Sándor Nagy. "Publication of book dealing with Hungary. The May 21 issue of the Délamerikai Magyarság informs that the largest Argentine publisher, Editorial Kraft, will soon publish the white book of the counterrevolution in Spanish. Actually this book already appeared in bookstores in Buenos Aires; its author is Melvin J. Lasky. The original edition is by Martin Secker, Vanburg LTD. London. The book is a collection of documents on the echo of the counterrevolution abroad, illustrated with some of the photos already known in Hungary. The price is 250 pesos. Should you find it necessary to acquire it, please let us know as soon as possible." 
outrage - all these sowed uncertainty among the Embassy's employees. In their reports to the Hungarian Foreign Ministry, they emphasized that the Argentine media were spreading "the wildest news about the events in Hungary" and that the fierce attacks on the Soviet Union, the Communist movement, and the Kádár-régime were done with the full support of the Argentine government. Undoubtedly, they said, the events provided ammunition for the enemy camp and mobilized all the "reactionary forces." On November 10, 1956, ambassador Sándor Nagy sent the following report to the Hungarian Foreign Ministry:

[Courtesy visit to Vice-President Rojas]. "I inform Comrade Minister that the Argentine Vice-President Rojas received me on November 8.... It surprised me that he would do it right now, when the Argentine press, radio, television and propaganda spread the wildest news about the events in Hungary. It is evident that with support of official organisms a strong attack is being directed first against the Soviet Union, but also against the whole Communist movement. Apart from an attack initiated against the Kádár administration, we [the embassy] are not being attacked, but at the same time, unfortunately, our "fame" has grown among reactionary elements. The Hungarian events armed the enemy camp and mobilized all reactionary forces. It seems probable to me that Rojas was prompted by this situation when he received me right now. I was prepared that he would put provocative questions to me, as he did to the Checoslovakian ambassador Pavlicek, when receiving him. ... I set forth that the present moment was not appropriate for the visit, I would have preferred it to occur in a calmer atmosphere. He answered that it didn't matter that there was unrest in Hungary, they understood it, and that their feelings are with the Hungarian people. (He probably was thinking of something different than I). ${ }^{13}$

On December 10th, 1956, the Hungarian Foreign Ministry issued strict instructions to the Embassy in Argentina (regarding the observation of the lives of the Hungarians who arrived in Argentina and neighboring countries): In view of the fact that as a consequence of the events more than a hundred thousand Hungarians emigrated to the West, many of whom wanted to settle in Argentina, Chile, Bolivia, and Uruguay, the work among Hungarians must be intensified. Therefore, the Embassy was to observe closely the lives and numbers of the Hungarians recently arrived in those countries. It was to monitor the immigration process and investigate the kinds of activities the so-called "reactionary" Hungarian institutions organized for the newcomers, what help these were getting, and through which organizations. ${ }^{14}$

The situation of the Communist foreign representatives became critical, not only vis- $B$-vis the Argentine authorities and people, but within their own camp as well. A number of members of the Hungarian Embassy defected. The Budapest Office of Hungarians Abroad was especially concerned by the fact that a large number of members of supposedly "loyal groups" changed their political allegiance and withdrew from their clubs. The Office saw it as its primary responsibility to intensify activity in the so-called "progressive and loyal" émigré organizations, in order to be able to rely on them to increase propaganda material in the press. ${ }^{15}$

A year later - in December 1957 - the Foreign Ministry detailed the guidelines regarding the Embassy's role among the right-wing émigré organizations in Argentina. It ordered the

13 11.10.1956 MOL XIX-J-1-j. Arg. 4/j. MNK 334/szig.titk./56 KÜM 007987-335/56, 5.d.

14 12.10.1956 MOL XIX-J/1/j. 20/a 10. D. KÜM-007923

15 12.9.1957 MOL XIX-J-1-j-Argentina 005471/1957, 20/a, 10. d. 
Embassy to closely watch and report on the organizations, their leaders, and their press. The goal was infiltration and the creation of animosity among these groups. A favored strategy was to lure prominent but less "reactionary" personalities back to Hungary, as a way to further undermine émigré morale:

... We find it especially important to observe from now on the activity of international émigré organizations, such as the League of Captive Nations, the International Anti-Bolshevist Organization, the Free Europe Commission, that are the common international organizations of right-wing émigrés of the Soviet Union and of the other popular democracies, such as the National Committee, the Community of Camaraderie of Hungarian Ex-Fighters, the Revolutionary Council of Strasbourg (Kéthly, Király, Kővágó), the Freedom Fighters' Association organized by Béla Király, the Social-Democrats' activities in different countries, as well as the organizations of writers and other intellectuals. Moreover, we want to receive information permanently from our embassies on the fascist organizations of the right-wing émigrés in each country.

The right-wing Hungarian émigré organizations and its members carry out significant activity that is harmful to the Argentine masses as well. Even before the counterrevolution, émigré organizations of considerable influence operated in Argentina (for example the Centro Húngaro, the Community of Camaraderie of Hungarian Ex-Fighters, etc.) During and after the counter-revolution, their activities intensified. Their temporary strengthening was due primarily to the fact that keeping the so-called Hungarian issue alive was in the interest of Western imperialist circles. The activities of these right-wing organizations and personalities are in many instances supported politically, economically and morally by official Argentine circles. ${ }^{16}$

Clearly, of major concern for the Hungarian Foreign Ministry was not only the actual political mobilization of the émigrés, but also its perception that their efforts were actively supported by the Argentine government. Thus, after the 1956 revolution, Bolshevist propaganda became very intense in Argentina as well. Every effort was made to tarnish the reputation of the revolution. The book Tormenta en Hungría [Storm in Hungary] exalted János Kádár - a party leader who betrayed the revolution - as the personification of the heroes who defended "the building of Socialism in Hungary". ${ }^{17}$ In 1957, the Hungarian Foreign Ministry planned an exhibition for October 23rd, documenting the counterrevolutionary character of the uprising. However, these documents never arrived in Argentina, and the exhibition organized in August of 1958 in the left-wing club Törekvés had little impact, with only about 150 attendees. ${ }^{18}$ Diplomatic relations between the Hungarian People's Republic and Argentina did not improve after the revolution. In fact, they worsened during the left-wing government of Arturo Frondizi as a consequence of the execution of Imre Nagy, Hungary's Communist Prime Minister who had sided with the revolution.

As for relations between émigré organizations in Argentina and the Hungarian Government, these ranged from nonexistent to strained at best, until the eventual lifting of the Iron Curtain in 1990.

16 12.9.1957 [MOL XIX-J-1-j- Argentína 005471/1957, 20/a, 10.d.] Sándor Nagy "Tasks regarding the emigration in Argentina"

17 7.2.1957. MOL XIX-J-K-Arg-4/j-1957, 3.d.

18 3.28.1957 MOL XIX J-1-j-001747/57 TÜK 4/j, 5.d. 
(Excerpted and translated from Chapter 4 of the author's book: "Szabadságom lett a börtönöm“. Az argentínai magyar emigráció története. 1948-1968. ["My freedom became my prison". History of the Hungarian Emigrés to Argentina. 1948-1968]. Budapest: A Magyar Nyelv és Kultúra Nemzetközi Társasága. 2003.) 